\title{
A LITERATURE REVIEW: POSTMODERNISM AND HISTORIOGRAPHIC METAFICTION
}

\author{
Mohammed Abdul Hussein Muneer \\ $D G$ of Education in Babil \\ DOI: $10.37648 / \mathrm{ijrssh} . v 10 \mathrm{i02} .012$ \\ Received:12 $2^{\text {th }}$ January, 2020; Accepted:08 ${ }^{\text {th }}$ February, 2020; Published: $26^{\text {th }}$ February,2020
}

\begin{abstract}
This review is an attempt to study historiographic metafiction as a term which is proposed by Linda Hutcheon. By using this term, Hutcheon tries to produce a relationship between the world and literature by combining the fictional elements with the historical events. This paper also contains an analysis about the characteristics of historiographic metafiction.

Key Words: postmodernism, historiographic metafiction.
\end{abstract}

Malcolm Bradbury gives a summary about the directions in British fiction between 1979 and 1990 in which he determines an inclination in this kind of novels towards history, specifically in the fictions of the 1980s and he says:

"Certainly exploring past and recent history, at a time when its progress seemed either ambiguous or disastrous, and many of the progressive dreams of the earlier part of the century had plainly died, and did become a central theme of Eighties Fiction (Bradbury, 1993: 432).

According to Bardbury, this inclination is the outcome of the expansions concerning the historical scope. During the $19^{\text {th }}$ century, history was observed "as an empirical search for external truths corresponding to what was considered to be absolute reality of the past events"(Onega, 1995: 120). This idea is disapproved by later historians and one of them is Hayden White. White clarifies his view on history in his Metahistory. His arguments are structured according to the opinions of certain authors just like: Derrida, Genette, Foucault and Barthes. White restricts the purpose of the concept 'metahistory' in discovering certain solutions to specific inquiries that are associated with the epistemological condition of genetic captions and the supposed shape of reflection in the presentation of history (White, 1973: 9).

Hayden White suggests in 'Metahistory' a notion of fiction which sketches harmonization amidst history and literature. White states that the classical historiography utilizes recitation shape where historians transfer the historical information and he scrutinizes "deep structure of the historical imagination." According to him, all kinds of history consist of a profound oral framework and the official notion is required to scrutinize this framework (Hutcheon, 1989: 113).

After that, in "Historical Text as Literary Artifact", Hayden White emphasizes the view that the writing of history contains the procedure of 'employment' where documents are transferred into tales. According to White, it is an important process as "histories gain part of their explanatory effect by their success in making stories out of mere chronicles"(White' 2001: 
223).Furthermore, White argues that historical facts "can be emplotted in a number of different ways, so as to provide different interpretations of these events and to endow them with different meanings" employing various doctrines and particular philosophies of life or conceptions of the world (Ibid: 224). Furthermore, Hayden White focuses on the fact that a historian is able to track down the previous situations which are found in historized registrations, scripts or records, yet the historian cannot attain the circumstances of the previous actions. Thus, the historian has to create certain situations to make the previous action more important and more significant. Then, White refers to the fact that the environment where those archives occur is unattainable, therefore, this environment is not offered but created (Ibid: 228). The arguments of White bridges the hiatus that is found amidst literature and history. This hiatus is expanded by the efforts of those historians who attempt to create a balance between historical accounts and sciences.

In addition, the historical novels in the eighties take a new form and they are different from the novels which are written in the previous years.

In this era, it is found that the historical figures, situations and archives are inserted in the historical novels.

Linda Hutcheon produces a new tendency in postmodern historical fiction and she tags it "historiographic metafiction" as it presents the theory of modern historiography as an important theme and complicates the differences which are found between fantasy and history. She says "historiographic metafiction puts into question, at the same time as it exploits the grounding of historical knowledge in the past real. This is why she has been calling this historiographic metafiction"(Hutcheon, 1889: 113). It is found that Hutcheon's definition is controlled by the opposition that is explored by the interweave between the self- reflexivity and the historical truth in the narrations, "novels which are both intensely selfreflexive and yet paradoxically also lay claim to historical events and personages"(Ibid).

It is stated that 'Historiographic metafiction' is not only interested in the inquiry which is related with 'truth- value' of thematic genetic impersonation; however, it is interested in the inquiry of who cogs history and the historical events. Thus, within 'historiographic metafiction' there is an opinion which states that the historical information is structured according to certain ideologies. Hutcheon states that: "All past 'events' are potential historical 'facts', but the ones that become facts are those that are chosen to be narrated. [...] This distinction between brute event and meaning- granted fact is one with which postmodern fiction seems obsessed"(Hutcheon, 1991b:75).

Therefore, 'historiographic metafiction' focuses on the historical events and the historical figures whom history chooses to eliminate them, and their tales are narrated . In addition, it is illustrated that substitutional histories are constructed within 'historiographic metafiction'.

Furthermore, historiographic metafiction expresses the quiet histories of peripheral groups by destroying the previously agreeable presentation for the sake of imposing this interpretation out of the core, and discovering the eliminated histories of other historical figures.

Hutcheon argues that the purpose of historiographicmetafiction is "to note the dispersing interplay of different heterogeneous discourses," so she states:

\footnotetext{
"What has surfaced is something different from the unitary, closed, evolutionary narratives of historiography as we have traditionally known it: [in historiographic metafiction] we now get the histories of the losers as well as the winners, of the regional (and colonial) as well as the centrist, of the unsung many as well as the much sung few, and $[\ldots]$ of women as well as men" (Hutcheon, 1991b: 66).
}

It is said that 'historiographic metafiction' is maniac of the historical events and historical figures, and it is interested in the historical events. It uses history as its main topic and comments on the study of historical writing. It is argued that 'historiographic metafiction' produces a mixture between the metafictional aspects and pays a specific awareness to the study of history, which consists of three styles: theory, history and literature. This tendency refers to the literary 'self- conscious' integration between imagination and history. The postmodern view defies 
the division between history and literature: both of them are methods of writing, intertextual and linguistic structures. Since imagination and history are considered to be human structures, it is said that 'historiographic metafiction' concentrates on "rethinking and reworking of the forms and the

contents of the past"(Ibid: 5). Historiographic metafiction elevates the problem of what the writing about history involves, inquiring about the emotion and the different potential presentations of the past. According to Linda Hutcheon, historiographic metafiction is originally paradoxical: it labors within certain agreements for the sake of destroying theses conventions. It is argued that historiographic metafiction have to remain alive in relation with dual consciousness of its imagination and its basis in actual actions.

Historiographic metafiction consists of two terms: historiography and metafiction. Historiography is defined as "the study of the way history has been and is written- the history and historical writing... When you study 'historiography' you do not study the events of the past directly, but the changing interpretations of those events in the works of individual historians"(Furay and Salevouris , 1988: 223). Patricia Waugh (1984:2) defines metafiction as "a term given to fictional writing which selfconsciously and systematically draws attention to its status as an artifact in order to pose questions about the relationship between fiction and reality."Metafiction refers to the fantasy that expresses itself. It clarifies its framework, and it explains its state as a fantasy. The writer calls his/her readers for their voluntary comments of ingratitude. According to the metafictional view, the readers should not ratify in imagination, they should not passively get in the imaginative universe. It is found that the universe which metafiction describes does not refer to the actual universe to which it is similar. Malcolm Bradbury argues that:

"The novelist today may feel himself under a growing need to present his fictions as fictive- because the problems of presenting the structure of a novel as authoritative or somehow co- equal with life are intensified and obscured where there are no communal myths or ethics. Novelists use language to explore contingent reality and not to create systematic orders.
There is not a necessary order to present any longer" (Bradbury, 1973: 264).

According to Hutcheon, "the meeting of metafiction and historiography produces a new kind of experimental writing uniquely capable of fulfilling the poetics of postmodernism"(Hutcheon, 1995:71).The expression 'historiographic' uncovers the crucial attention in history, furthermore, it uses metafictional techniques to underscore the idea that history refers to a structure and it does not refer to a normal object with which is connected in the past. Metafiction stresses the fact that the readers must realize that historical events are understood only by using other texts. This means that all the historical exporters are intertextual. It is said that parody and intertextuality play an important role in postmodern literature: historiographic metafiction transfers its attention towards the intertexts which are found in literature and history. In postmodern theory, it is argued that the readers can only realize the truth as it is presented and continued by using the ethnical performance of it. It is stated that the readers make certain experiments in the universe by using their past and present enumeration of it (Capra , 1985: 128). Intertextuality is defined as "an observation of relationships between texts that places the generation of meaning in the dynamic conversation between text/ intertext/ reader"(Giere , 2009:3). The term 'intertextuality' is ascribed to Julia Kristeva, who developed this concept in a systematic way in her work Semiotike.

Intertextuality refers to the relationship between texts. According to Kristeva, intertextuality refers to the way in which readers spin together new texts from incalculable other texts and so rewrite every text. The key component of Kretiva's perspective is that intertextuality erases the boundries between literary texts. Julia Kristeva says"the text is therefore a productivity, nad this means... that it is a permutation of texts, an intertextuality: in the space of a given text, several utterances, taken from other texts, intersect and neutralized one another"( Kristeva , 1989: 113). Julia illustrates that, instead of analyzing texts in the traditional way, a typology of texts is needed, and it is produced by "placing them within the general text (cultural) of which they are part, and which is in turn, part of them"(Kristeva,1980: 36). For her, studying text means taking into consideration the society and the history of that text ( Ibid: 37). In addition, she 
emphasizes that all texts are an absorption and transformation of other texts. Kristeva argues that any given text is "constructed as a mosaic of quotations, any text is absorpation and transformation of another" (Ibid: 66).

Depending on Linda Hutcheon's point of view, one of the features which distinguishes historiographic metafiction from traditional historical and from historiography is the use of intertextual parody: "the textual incorporation of

these inter- textual past(s) as a constitutive structural element of postmodernist fiction functions as a formal marking of historicity- both literary and worldly. At first glance, it would appear that it is only its constant ironic signaling of difference at the very heart of similarity that distinguishes post- modern

parody from medival and Renainssance imitation"( Hutcheon ,1995: 4). It is stated that mockery and satire have been connected with parody, but the concept of postmodern parody is linked to intertextuality and metafiction. Parody is defined by Hutcheon as "parody is [...] repetition with critical distance, which marks difference rather than similarity"( Hutcheon, 2000: 6). By using the concept of 'parody', the writer is looking at the historical state of literature, specific parts are assigned which the writer discovers and represents in new ways. In addition," the parodic representation exposes the model's conventions and lay bare its devices through the coexistence of the two codes in the same message"(Ibid: 6). It is clear that parody is connected with both intertextuality and metafiction, but the essential variation between the three terms must be clarified. It is found that parody is noticeable as a style of its own where it reiterate its substances. Parody has often been connected with mockery and humor; however, in Linda Hutcheon's point of view, they are inevitably linked. Moreover, irony is considered to be a specific element of parody as irony is the element that clarifies the crucial variation of the mimicry or repetition "parody [...] is a form of imitation, but imitation characterized by ironic inversion"(Hutcheon , 2000: 165). A 'parody' does not just represent an imitation of any text, it requests the addresser's purpose to parody in addition to the addressee's realization of the parodic icons(Ibid: 37). Furthermore, the use of parody demands a reader that possess specific cultural development and information about the parody's environment, communication and symbol, to understand the double voiced message. Hutcheon states that parody refers to one of the most prominent styles in postmodernism since it"restores history," as

it simultaneously " questions the authority of any act of writing"(Ibid:129). It is found that 'parody's' "range of intent- from the ironic and playful to the scornful and ridiculing,"(Ibid: 6)is one condition for its capacity to work as both criticism as well as damage. In addition, Hutcheon says that in postmodernism, the tendency to understand literary and historical texts as a common possession of society returns: "but it is a return made problematic by overtly metafictional assertions of both history and literature as human constructs, indeed, as human illusions- necessary, but nonetheless illusionary for all that"(Hutcheon ,1995: 4). According to Hucheon, the importance of intertextual parody lies in the fact that it lets the readers experience the past more closely; however, it is just the past that they are able to recollect from textual sources (Ibid: 31 ).

It is found that historiographic metafiction produces an argument within imagination in which it limits the methods where history is going to be used and realized. Linda Hutecheon argues:

"Historiographic metafiction shows fiction to be historically conditioned and history to be discursively structured, and in the process manages to broaden the debate about the ideological implications of Foucaldian conjunction of power and knowledge- for readers and for history itself as a discipline" (Ibid).

It is stated that 'theory' represents the third style which structures historiographic metafiction. 'Historiographic metafiction' is constructed on the reciprocal reliance of imagination and the critical theory. It is said that during the postmodern era, the authors are associated with the question of structuring a

decisive history. 'Self- reflexivity' is an essential characteristic that describes all of the postmodern historical fictions since they speculate on sending and receiving the historical events. The self- reflexivity of historiographic metafiction makes the readers inquire about their information about the past and the methods that they have gained such information. In historiographic metafiction, the reader is compelled to admit not only the sources of his/her knowledge of the historical events, but they have to admit the importance and the restrictions of this inevitable logical shape of information (Hutcheon ,1989: 127). 
There are certain features which characterize historiographic

metafiction and one of them is its attitude towards the truth. Hutcheon notices that postmodernism is interested in multiplicity of truths rather than in making a distinction between the truth and the lie as it was in the periods before

(Ibid: 108).

Consequently, these terms lose their meaning:

"Historiographic metafiction suggests that truth and falsity may indeed not be the right term in which to discuss fiction, but not for the reasons offered above. Postmodern novels like Flaubert's Parrot, Famous Last Words, and Maggot openly assert that these are only truths the plural, and never on truth; and there is rarely falseness per/se, just others' truths"(Ibid: 35).

Finally, the most important feature which distinguishes historiographic metafiction from the traditional historical fiction is the fact that the former one intentionally changes and deactivates history. This tendency has a specific purpose as Linda Hutcheon notes: "the historiographic metafiction plays upon the truth and lies of the historical records. In novels like, Foe, Burning Water or Famous Last Words, certain known historical details are deliberately falsified in order to foreground the possible mnemonic failures of recorded history and the

constant potential for both deliberate and inadvertent error"( Ibid: 115). Thus, the purpose of changing historical knowledge in historiographic metafiction is to remind the readers that it is necessary to question the facts which are taken for granted. Hutcheon says that postmodern metafiction rewrites and represents the past in narration as well as in history in order to prevent its rigidity (Ibid: 110).In spite of the fact that historiographic metafiction disrupts the past, but it does not mean that it denies it fully, as Hutcheon claims: "this does not deny that the past "really" existed, it only conditions our mode of knowledge of that past. We can only know it through its traces, its relicts"(Hutcheon, 1989: 119). Historians claim that they build the world of words on abstract reality which forms history, while historiographic metafiction questions the reality of these texts by using the events of the past that actually happened to some historical characters adding some imaginative perspective or role for these characters by the writers, and the reader himself/ herself takes the part to make an end that suits their ideology or their interpretation of the past. A good example of it is Chatterton a novel which is written by Peter Ackroyd the postmodernist writer who creates his world in a text that examines the reality of the poet Chatterton who took an arsenic to finish his life in the age of 17. Peter Ackroyd is facing his readers by two other endings for Chatterton's life when the imaginative character, the poet Charles is in front of a portrait for Chatterton in his middle age. This situation makes the reader reexamines the history. At the end of the novel, we see Chatterton, Charles and Hardy go along together. In this way, Peter Ackroyd is questioning the history by putting these three characters in one time, while they lived in three different centuries.

In Ackroyd's Chatterton, the author firstly defies the idea that the poet Chatterton commits suicide by making him dies happily. Ackroyd's purpose behind changing a lot of the historical facts is to make the readers involved in his narratives to explore the truth by themselves. During the eighteenth century, Chatterton commits suicide by swallowing poison (Saglam, 2012: 66):

"On the $24^{\text {th }}$ of August, 1770, Thomas Chatterton, at the age of seventeen years and nine months, overcome by despair and distress, terminated his clouded career by swallowing poison- according to the best authorities, arsenic in water, and died in consequence the next day." (Chatterton: 292)

In this narrative, the novelist defies the traditional biographic story in different forms by using the techniques of historiographic metafiction. Peter Ackroyd says that when Chatterton drinks the arsenic that is blended with alcoholic drink, the persona uses it as a therapy for the gonorrhea. When the character drinks this mixture he is very happy and Ackroyd says "He is on top of the world" (Chatterton: 223). So that, Ackroyd invents a big gap between the two stories, whether chatterton commits suicide or not (Saglam, 2012: 66).

Peter Ackroy's Hawksmoor (1985) is another example for the use of the techniques of historiographic metafiction and metafiction. Ackroyd's novel recounts analogous narratives of 'Nicholas Dyer' who constructs seven churches during the eighteenth century London, so he wants epidermal oblations and 'Nicholas Hawksmoor' who is a detective during 1970s, he probes 
homicides which are committed in the same churches that are built by Dyer (Wikipedia, 2018).

It is found that Hawksmoor is the engineer of the seven churches during Queen's Ann era, while Hawksmoor is an investigator in the fictional world that has been invented by Peter Ackroyd. The persona of 'Nicholas Dyer' in Ackroyd's narrative depends on the character of the eighteenth century designer (i.e. architect) 'Nicholas Hawksmoor' (1661- 1736). Peter Ackroyd decides to substitute the denomination 'Hawksmoor' in the $18^{\text {th }}$ century to the $20^{\text {th }}$ century investigator to give an idea that he is a metempsychosis of Dyer 'the killer' (Saglam, 2012: 131).

There are certain differences the character of Dyer during the $18^{\text {th }}$ century and the persona of Dyer during the $20^{\text {th }}$ century. In spite of the fact that Nicholas Hawksmoor is born in 1661, yet in Ackroyd's Hawksmoor Dyer is born in 165. Another difference is that the ancient Dyer is born in Nottinghamshire, whereas Peter Ackroyd locates Dyer in a huge city after that he is moved to London (Ibid).

It is stated that through the use of historiographic metafiction Ackroyd's story questions certain topics which are associated with science and faith during the two centuries ( Smethurst, 2000: 179).

The first part of Ackroyd's Hawksmoor takes place during the $18^{\text {th }}$ century London and this era is the period of Enlightenment. The second part occurs in London during 1970s and this period refers to the incline of modernistic science and logical cognition. Smethurst (2000: 181) says that Ackroyd's novel is considered to be a trick, since the modernistic science that is obtainable to Hawksmoor (i.e. the detective) is not going to resolve the secret. Smethurst adds that the postmodern reader's will is to find an inference to the secret, to conclude the text and he/ she does this just to be convinced by amusing the non- linear time of a quietism which is found in the $18^{\text {th }}$ century by modernistic science and logical thought (Ibid).

Ackroyd's Hawksmoor is considered to be an intertextual text, as the two novels resemble each other. The novelist reiterates the same expressions, characters and topics. The two novels occur in the same place (i.e. London). It is found that Dyer works in the office of Queen Ann in Scotland Yard, while Hawksmoor's office occurs in new Scotland Yard. Both of the major characters in the two centuries dwell around seven dials and the homicides are committed on the ground of the same seven churches (Ibid).

Ackroyd's narrative rotates between a group of chapters that take place in the early $18^{\text {th }}$ century London and a group of chapters that occur in the $20^{\text {th }}$ century. The first group of chapters is associated with the architect 'Nicholas Dyer'. This architect is charged by Parliament to construct seven churches. Those chapters are associated with Dyer himself in the years 17111715. During this era, London is being reconstructed after the Plague and the great fire of 1666. The major architect during this era is 'Sir Christopher Wren', wheras the adjutant surveyor is 'Dyer'. In Ackroyd's novel, Dyer refers to "of that older Faith" (Hawksmoor: 20), a belief which is an odd blend of ancient time, magician and Satanist rituals. Dyer's spiritual faith in the prevalent potential of wickedness is on the contrary of Christopher Wren's faith in the experimental, scientific and logical behaviours of the royal community. It is found that Dyer makes clear from the beginning that he rejects the soul of the Enlightenment and he has a belief in the forces of dimness" He who made the World is also author of Death, nor can we but by doing evil avoid the rage of evil Spirits" (Hawksmoor: 20). He covertly immolating to the satanic forces a virgin boy in the bases of each church (Smethurst, 2000: 181).

The second part of the narrative is concerned with 'Nicholas Hawksmoor'. He is a detective chief investigator who is discussing an odd set of strangulations of boys which takes place on the places of Dyer's churches. Hawksmoor is considered to be Wren's modernistic parallel whose faith in the force of cause fails to resolve the homicides (Ibid). Ackroyd's story also describes the opposition to logical science and liaison to the ancient belief and metaphysical thought in the persona of 'Nicholas Dyer' (Ibid).

According to the ancient belief, the fallen universe is basically wicked and the human beings are full of guilts; however, they can rescue themselves:

"And thus we pray: what is Sorrow? The Nourishment of the World. What is Man? An Unchangeable Evil. What is the Body? The Web of Ignorance, the foundation of all Mischief, the bond of Corruption, the dark coverture, the living Death..." (Hawksmoor: 21)

It is found that Dyer believes in naturalistic time that unites past, present and future. Smethurst (2000: 
185-6) discusses that the continuation of time should be engraved in the layout and the structure of Dyer's churches, therefore time can be understood just like the regularity of the orbits, reechoing through a limited universe in which time is previously finished...From a postmodern point of view, it is true that the widening world includes the trail of events from the last millions of years, since they move in light waves through the ether.

Dyer has a policy in which he is going to use old styles, just like pyramids and obelisks in the design of his churches and to pursue the old rites and rituals in the building, just like sacrificing a virgin boy and entombing the corpse in the bases, he says:

"This Mirabilis once describ'd to me, viz a corn when it dies and rots in the Ground, it springs again and lives, so said he, when there are many Persond dead, only being buryed and laid in the Earth, there is an Assembling of Powers. If I put my Ear to the Ground I hear them lie promiscuously one with another, and their small voices echo in my church: they are my Pillars and my Foundation" (Hawksmoor: 24).

It is stated that the persona of Wren refers to the belief in the modern logical science which controls the $18^{\text {th }}$ century thought and that attempts to ruin the old faith regulations, yet by presenting Wren's character, this belief overwhelmingly confirms to be wrong, as in Dyer's commentary on the church of 'St Paul's Cathedral', he says:

"He likes to destroy Antient things: sad and wreched Stuff, he called it, and he u'ed to say that Men are weary of Reliques of Antiquity. He spoke in their stead of Sensible knowledge, of the Experimental Learning and of real Truths: ... This is our Time, said he, and we must lay its Foundacious with our own Hands... when it came to his Notice that he was building St Pauls Church upon Ancient Ruin" (Hawksmoor: 55).

It is illustrated that Dyer and Wren refer to the faith which has basically various notions of time:

"Our Age can... lay the Foudacious: that it is why we must study the principles of nature, for they are our best Draught" (Hawksmoor: 144).

At the beginning, the investigator Hawksmoor is introduced as a modernistic match to Wren. Hawksmoor relies on the identical time awareness and belief in 'causality'. He depends on new scientific methods, just like computers and other technologies to restructure the offense scenery (Smethurst, 2000: 190).

Hawksmoor's logical methods are similar to Wren's methods. It is found that by depending on science, new technology, reason and result, physical proof, Hawksmoor stays restricted in the present, incapable to visualize the past or foretell the future. It is discussed that Hawksmoor is introduced as a 'parody' of a modernistic investigator, all methodology and cause, yet no prudence of conjecture (Ibid: 192).

With the progress of the narrative events, Hawksmoor is considered to be an inventor rather than a constructor of the past: the transport from cause and procedure to fantasy and imagination. As a persona in a postmodern narrative, he is not away from avowing that he is a concoction, and Hawksmoor has a selfawareness that there is a person in the past is rigging him (Ibid: 193).

As the events of the novel expand, Hawksmoor turns into Dyer's counterpart. The connection between Hawksmoor and Dyer through different centuries is clear, when Dyer and Wren call Bedlam to view a demoniac. Dyer sounds an odd prophesy:" And in his Madness he called out to me again: Harkye, you boy! I'll tell you some what, one Hawksmoor will this day terribly shake you!" (Hawksmoor: 100)

When Hawksmoor pays a visit for his father in the house of the old people, there is an old man who tells a letter obviously intended for Dyer: "Nick, he said, 'Nick, is there still more to come? What happened to that letter? Did they found you out?" (Hawksmoor: 121)

Eventually, in the only fanciful building (i.e. Little St. Hugh church) Dyer stashes a conspiracy which will finally drag Hawksmoor into this abbey to explore his mystery:

"Nor shall I leave this place once it is completed: Hermes Trismegistus built a Temple to the Sunne, and he knew how to conceal himself so that none could see him tho' he was still within it. This small now suffice for a present Account, for my own History is a patern which others may follow in the far side of Time. And I hug my Arms around myself and laugh, for as if in a Vision I see some one from the dark Mazes of unknown Futurity who enters Black Step Lane and discovers what is hidden in Silence and Secresy" (Hawksmoor: 205)

At the epilogue of Ackroyd's narrative a spiritual conversion happens since the tired Hawksmoor 
(IJRSSH) 2020, Vol. No. 10, Issue No. II, Apr-Jun

eventually links Dyer's style with the style of the crimes that are committed in the present day. He visualizes that he indeed subtends Dyer in his church:

" And his own Image was sitting beside him... and when he put out his hand and touched him he shuddered... They were face to face, and yet they looked past one another at the pattern which they cast upon the stone..." (Hawksmoor: 217)

To conclude that Postmodernist theorists and critics claim that historiographic metafiction and metafiction are new brand techniques of writing, but in fact if a reader go back to $13^{\text {th }}$ century for Ibin Tufail's novel Haae Ibin Yaqthan, it is a good example for the use of metafiction and historiographic metafiction which is full of intertextuality and parody referring to the Holly Quran, when the prophite Moses had been thrown in the sea in a basket as a result of fearing pharaoh of Egypt when he was a baby child. When the author refers in his writing that whatever he has written is from his imagination which is called a self- awareness and a self- reflexive with narcissism of his writing so this improve that western writers did not invent such a style of writing.

\section{REFERENCES:}

Ackroyd, p. (1985) Hawksmoor. London: Hamish Hamilton.

(1987) Chatterton. New York: Ballantine

Books.

Bradbury, M. (1973) Possibilities. Essays on the State of the Novel. Oxford: Oxford University Press.

(1993) The Modern British Novel. London:

Secker \& Warburg.

Dominick La Capra (1985) History and Criticism. New York: Cornell University Press.

Furay and Salevouris (1988) The Methods and Skills of History: A Practicle Guide. ISBN.
e-ISSN: 2249-4642, p-ISSN: 2454-4671

Giere, S. D. (2009) A New Glimpse of Day One: Intertextuality, History of Interpretation and Genesis. New York: Walter de Gruyter.

Hawksmoor, Petr Ackroyd- 'Wiki, http:// en.m. Wikipedia.org.

Hayden White (1973) Metahistory: The Historical Imagination in the Nineteenth- Century Europe. London: John Hopkins UP.

(2001) "The Historical Text as Literary Artifact" in The History and Narrative. Ed. Geoffrey Roberts. London: Routledge.

Hutcheon, L. (1989) The Poetics of Postmodernism. London: Routledge.

(1991b) The Politics of Postmodernism.

London: Routledge.

(1995) "British Historiographic Metafiction," in Mark Currie, Metafiction. New York: Longman House

(2000) A Theory of Parody. Illinois: Illinois University Press.

Julia Kristeva(1980) Desire in Language: A Semiotic Approach to Literature and Art. New York: Columbia University Press.

(1989) Semiotike. Researches Pour une semanalyse (collections Tel Quel. Paris: Le Seuil

Onega, S. (1995) Telling Histories: Narrativizing History, Historcizing Literature. Amsterdam- Atlanta: Rodopi.

Salgam, B. G. (2012) Representations of London in Peter Ackroyd's Fiction. New York: The Edwin Mellen Press.

Smethurst, P. (2000) The Postmodern Chronotope. Amsterdam \& Atlanta: Rodopi.

Waugh, P. (1984) Metafiction: The Theory and Practice of Self-Conscious Fiction.

London:Routledge. 